\title{
Fungible Space: \\ Competition and Volatility in the Global Logistics Network
}

\author{
Martin Danyluk \\ Department of Geography \\ University of British Columbia \\ 1984 West Mall \\ Vancouver, British Columbia V6T 1Z2 \\ Canada \\ Email: martin.danyluk@ubc.ca \\ Forthcoming in International Journal of Urban and Regional Research \\ UNPUBLISHED MANUSCRIPT-NOT FOR ATTRIBUTION
}

\begin{abstract}
This paper examines an emerging form of interspatial competition premised on attracting cargo traffic and value-added logistics activities. Against the backdrop of economic globalization and the revolution in logistics, place-based actors are increasingly vying to insert their localities into transnational supply chains. I explore the causes, conditions, and consequences of this burgeoning growth strategy through a study of the dynamics surrounding the expansion of the Panama Canal, opened to shipping traffic in June 2016, and the consequent battle among North American ports to attract a new generation of oversized container vessels. The spatial practices of mobile actors in the logistics industry, I argue, represent the leading edge of capitalism's tendency to render places interchangeable-a condition I call fungible space. The abstract logic of spatial substitution, however, can never fully escape the concrete qualities of particular places, which form its very conditions of possibility. This dialectic of spatial fungibility and geographic specificity has intensified rivalries for volatile commodity flows and made logistics-oriented development a particularly risky growth strategy for cities. At stake in these speculative ventures is the welfare of vulnerable communities and workers who disproportionately bear the costs and risks of supply-chain volatility.
\end{abstract}

\section{Keywords}

Abstract space, logistics, entrepreneurial urbanism, economic globalization, urban governance 


\section{Introduction}

Figure 1 shows a map published in 2014 by Maersk Line, the world's largest containershipping company, providing schedule and route information for one of its transpacific eastbound services between Asia and North America. A careful look at the image reveals something peculiar: the route depicted on the map is neither transpacific nor eastbound. After departing from eastern China, ships deployed on Maersk's TP11 circuit sail west across the Indian Ocean, through the Suez Canal and the Mediterranean, and across the Atlantic to Newark, New Jersey.

How to make sense of this incongruous image? The immediate explanation is straightforward. Until recently, most ships carrying containerized cargo between Asia and the US East Coast did indeed travel across the Pacific, reaching the Eastern Seaboard by way of the Panama Canal. In 2013, though, Maersk Line and other ocean carriers began diverting some of this freight through the wider, deeper Suez Canal instead, al-

\section{Transpacific 11 (TP11)- Eastbound}
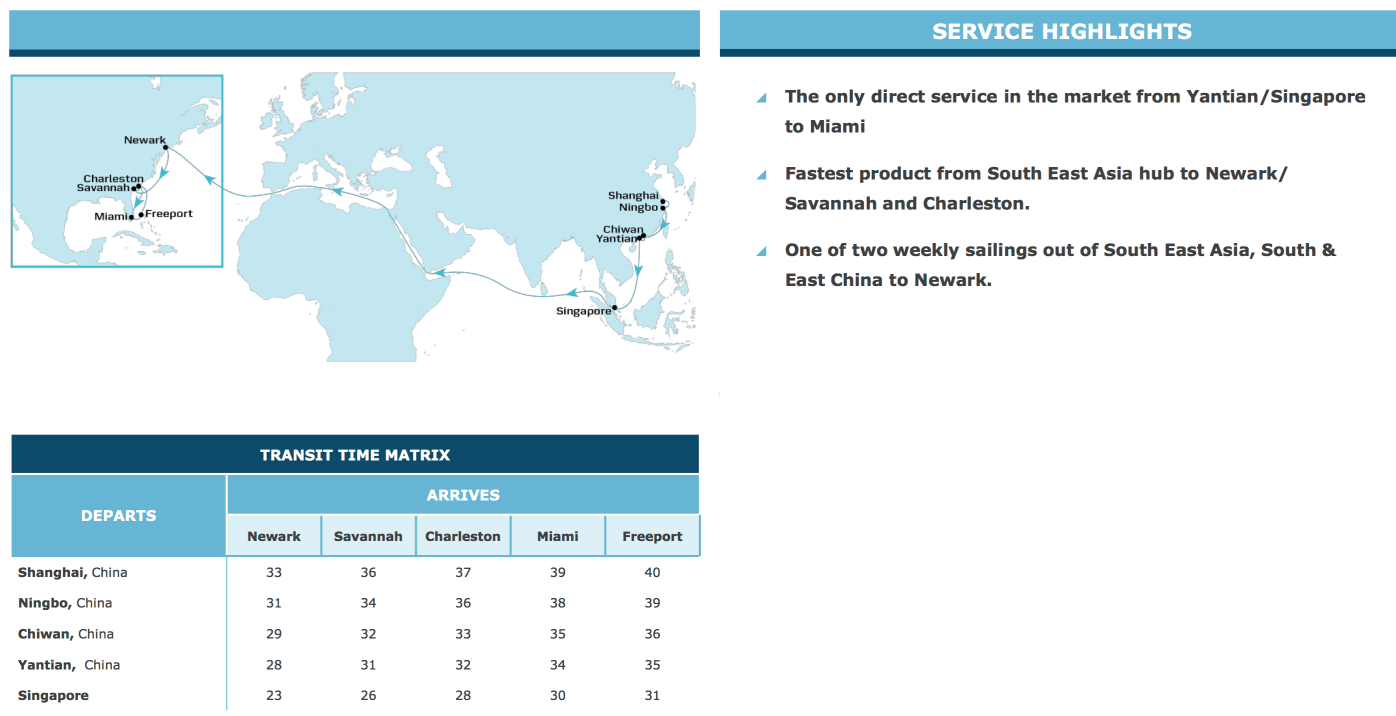

East China to Newark.

Figure 1. Maersk Line's Transpacific 11 Eastbound container service, 2014. Source: Maersk Group (2014) Routenet. URL http://www.maerskline.com/en-us/shipping-services/routenet/maersk-line-network/overview (accessed 30 December 2014). 
lowing them to use larger, more fuel-efficient vessels (Park, 2013). The label "transpacific" is a remnant of earlier shipping patterns, presumably retained by Maersk Line in order not to confuse its customers.

For urbanists and geographers, however, Maersk's routing decision and the associated map, in which an entire ocean has been replaced by another without comment, raise provocative questions. What has made it possible for places-port cities, shipping lanes, even whole expanses of sea-to be so readily substituted within the circuits of commodity capital? What forces are driving such drastic spatial transpositions? And what is at stake? These questions are closely related to another recent trend: the embrace of the logistics industry as an engine of place-based economic development and an object of interspatial competition. Over the past two decades, efforts to attract cargo traffic and value-added logistics activities have played an increasingly pronounced role in entrepreneurial growth strategies at the local, regional, and national scales. Yet, with only a few exceptions (Jaffee, 2015; Negrey et al., 2011; Wachsmuth, 2017), this development has received little attention in urban scholarship.

This paper probes the relationship between these two phenomena-the increasing substitutability of places within corporate supply chains and the intensification of competition among localities for commodity flows-through a multisited study of the container-shipping industry. It centers on the expansion of the Panama Canal, opened to shipping traffic in June 2016, and the consequent battle among North American ports to attract the new generation of oversized container vessels that can now use the waterway. As I show, recent developments in logistics have greatly enhanced the mobility of cargo, along with the ability of footloose industry actors to reshape their production and distribution networks. This newfound geographic flexibility has been actively exploited by manufacturers, retailers, and transportation providers seeking to drive down shipping costs and secure a wide range of routing options. The spatial practices of mobile actors in the logistics industry, I argue, represent the leading edge of capitalism's tendency to render places interchangeable-a condition I call fungible space.

Yet the abstract logic of spatial substitution can never fully escape the concrete qualities of particular places-qualities that form its very conditions of possibility. This dialectic of spatial fungibility and geographic specificity has intensified rivalries among places to attract volatile cargo flows and made logistics-oriented development an especially risky strategy for local officials and elites seeking to promote economic growth. At stake in these competitive ventures is the welfare of the communities and workers who live and labor in the arteries of global trade, as the costs and risks of supply-chain volatility are disproportionately borne by the most vulnerable actors in the network.

The article draws on a year of fieldwork conducted between 2012 and 2014 in Panama City, Los Angeles, and New York - three of the busiest container ports in the Americas-examining how actors in each region have been affected by and responded to the 
Panama Canal expansion. The research consisted of 73 semistructured interviews with industry, government, and community representatives; analysis of media coverage, policy and planning reports, and industry periodicals; participant observation within community-based organizations contending with the local impacts of freight movement; and nonparticipant observation at logistics industry conferences and trade fairs. The study's multisited research design instantiates what Ward (2010) calls a "relational comparative” approach to urban studies (see also Hart, 2006, 2016), making it possible not only to draw comparisons among the different study areas but also to trace the flows and connections that bind them together. The three port regions examined here are approached not as discrete individual cases but as interrelated nodes in a shifting global network.

The paper is divided into four parts. The first section provides an overview of the rise of logistics-oriented economic development schemes, contextualizing this emerging growth strategy in relation to the literature on entrepreneurial urbanism. The second section introduces the concept of fungible space. Building on Lefebvre's notion of abstract space, I argue that the historical development of capitalism is characterized by a tendency toward increasingly frequent and large-scale spatial substitutions. This trend is especially pronounced in the logistics industry, where recent developments have augmented the interchangeability of nodes and paths within global commodity circuits. In the next two parts, I explore these dynamics in action through the case of the Panama Canal expansion. The third section outlines the implications of the canal project for container flows and discusses the entrepreneurial strategies that logistics interests in Panama and North America have pursued to attract cargo traffic to their jurisdictions. Militating against any simplistic conception of fungible space, however, the fourth section shows that the very possibility of rendering places interchangeable is contingent on particular geographical conditions whose realization requires ongoing work. I also highlight the power of local political opposition to influence the shape of the wider network. Finally, in the conclusion, I consider some of the implications of logistics-based competition in an age of increasingly fungible space and increasingly volatile supply chainsboth for the place-based elites who seek to expand the throughput of the cargo network and for the populations who live and work in its paths.

\section{Competition for Cargo}

Scholars of cities are now well acquainted with the idea of entrepreneurial urbanism. Since the 1970s, urban and regional governance has become preoccupied with the goal of fostering economic development through attracting mobile capital investment (Hall and Hubbard, 1998; Brenner, 2003). As Harvey (1989: 4) observed in his seminal essay 
on the phenomenon, local governments in advanced capitalist countries have increasingly come to regard themselves as competitive actors and, accordingly, shifted their policy orientation from a "managerial" stance focused on the provision of local services and benefits to an "entrepreneurial" one emphasizing the creation of a friendly business climate. This changing approach to urban governance brings with it new political formations. Logan and Molotch (1987), in their theorization of the city as a growth machine, describe the influential role in shaping urban policy played by what they call "growth coalitions": alliances of place-based elites seeking to defend or enhance the value of geographically immobile assets (see also Molotch, 1976; Jonas and Wilson, 1999). The paradigmatic standard bearers of the urban growth coalition are representatives of the local rentier class-development, real estate, and construction interestsbut members may also include municipal governments, business associations, local media outlets, and labor unions. What unites these otherwise disparate actors is a shared interest in driving local economic growth through land-use intensification.

The entrepreneurial orientation of the urban growth machine is structured by, and itself serves to sustain, a wider field of interurban competition. That competitive logic is self-reinforcing: the more places that enter the race to attract footloose businesses and jobs, the more they indirectly enhance the relative power of mobile capital by providing it with an expanding menu of location options. "In selling themselves," Peck and Tickell (2002: 393) write, "cities are therefore actively facilitating and subsidizing the very geographic mobility that first rendered them vulnerable. . . The logic of interurban competition, then, turns cities into accomplices in their own subordination." In this way, the doctrine of urban entrepreneurialism becomes a self-fulfilling prophecy: the collective decision to engage in the game-and to believe it is worth engaging in-is precisely what brings the contest into existence and guarantees its perpetuation.

In his prescient diagnosis, Harvey (1989) posited that urban entrepreneurial schemes have four basic options available to them: cities may attempt to attract production activities, consumer spending, command-and-control functions, or redistributions from upper levels of government. Harvey's typology is complicated, however, by the global restructuring of capitalist activity that began in the 1970s and the concomitant rise of the field of business logistics. By "stretching the factory" (Cowen, 2014: 102) across planetary space, the logistics revolution has facilitated the development of a global circulatory system in which production and distribution, previously regarded as two discrete phases in a linear sequence of activities, are now densely interwoven. This functional and spatial reorganization of the supply chain has given rise to a new variation on the urban growth strategy in which the aim is not to entice investment into a locality but to redirect the flow of commodities through it. As Cowen (2014: 72) observes: "It is the activity of goods movement that is coveted, regardless of the final destination of the goods. ... Logistics - the management of supply chains-is a booming industry in 
itself with value added and spin-off economic activity." For local governments, businesses, and workers, the economic benefits to be had from increased cargo traffic include the jobs associated with moving, storing, processing, packaging, labeling, redirecting, and assembling goods, as well as the profits and tax revenues deriving from those activities and associated multiplier effects.

The embrace of logistics as a motor of economic growth can be attributed to two broad and interrelated shifts in capitalist organization since the 1970s. The first is the globalization of production. Offshoring and the global extension of supply chains have elevated the importance of physical circulation within the overall accumulation of capital. As corporate profits have come to depend on the rapid, efficient, just-in-time movement of raw materials, parts, and finished goods across vast distances, the logistics sector has become a key target of schemes to foster local economic development. This is especially the case in regions like North America and western Europe, which have experienced a loss of manufacturing jobs-in part a result of the same forces of global dispersal-and where policy makers are now seeking to promote alternative sources of employment (De Lara, 2012). A second driver of entrepreneurial efforts to attract cargo traffic is the wave of technological and organizational change known as the logistics revolution (see Allen, 1997; Bonacich and Wilson, 2008; Cowen, 2014). Since the 1960s, new technologies, management approaches, and business practices have greatly reduced the spatial constraints on transportation and distribution activities, enhancing the mobility of cargo. In turn, this newfound flexibility of corporate supply chains has intensified rivalries among places for footloose commodity flows.

Like conventional growth strategies, logistics-oriented development schemes are typically pursued through public-private partnerships involving an array of geographically situated actors, such as local and state governments, seaport and airport authorities, railroads, local business associations, labor organizations, and construction and real estate interests. Jaffee (2015) usefully distinguishes between those stakeholders with a specific interest in the growth of the goods-movement sector (e.g., trucking companies, warehouse developers, construction firms likely to benefit from infrastructure investment) and those whose interests are more diffusely tied to local economic expansion in general (e.g., the municipal chamber of commerce). While entrepreneurial initiatives to attract cargo flows are frequently organized at the urban scale, the expansive geographies of supply chains frequently necessitate the involvement of supralocal actors as well. In the United States, large-scale infrastructure projects often hinge on investment from upper levels of government, meaning that logistics-based growth efforts tend to be coordinated across some larger area, such as the metropolis, corridor, or state (Wachsmuth, 2017). Elsewhere, the circulation of commodities has become a nationalscale concern. Several fast-growing countries, including China, have placed logistics at the center of their economic development strategies (Sowers et al., 2014). National 
states' growing preoccupation with goods movement is evinced in-and has been fueled by-a recently devised World Bank ranking called the Logistics Performance Index, which compares countries in terms of infrastructure, customs processes, logistics services, tracking and tracing capabilities, timeliness, and ease of arranging shipments. The index, updated biannually, has prompted numerous countries to make investments in order to improve their logistics competitiveness (Cowen, 2014).

In important ways, then, logistics-oriented development schemes resemble growth strategies aimed at attracting more traditional production or consumption activities. One feature that distinguishes this emerging form of boosterism, however, is the intrinsically networked character of the activity being sought out, which makes possible complex relations of geographic interconnection and transposition. In the next section, I explore how recent developments in logistics have both enabled and impelled the substitution of places within the supply chain.

\section{Abstraction and Fungibility in the Global Logistics Network}

The increasing ease with which one locality may be swapped out for another within global commodity circuits is one manifestation of capitalism's propensity to remake space in ways that abstract from the concrete properties of particular places. Lefebvre (1991) viewed the proliferation of such an "abstract space" as a hallmark of capitalist modernity. Through the material and discursive practices of diverse social actors, he wrote, capitalism "tends to produce a space of its own," a distinctive geography fashioned by "abolishing spatial and temporal differences" and "destroying nature and nature's time" (326). Lefebvre believed that the worldwide extension of abstract space had become vital to the survival of capitalism during the twentieth century. The continued accumulation of capital and the reproduction of capitalist social relations, he claimed, were predicated on the production of an increasingly instrumental and all-embracing spatiality.

Abstract space, as Lefebvre saw it, serves two functions for capital. The first is to facilitate the production, circulation, and realization of surplus value. This implies, among other things, the perpetual reconfiguration of spatial relationships so as to promote corporate profitability. The exchange relations presupposed by money are "projected onto the terrain in the shape of relational networks (communications, markets) and of hierarchically organized centres (towns)" (Lefebvre, 1991: 120). Accordingly, in today's global economy-characterized by intensive and extensive flows of goods, materials, people, and information-the ongoing accumulation of capital implies the production of a dense planetary matrix of transportation and communication infrastructure, including an integrated logistics system to regularize the circulation of commodities 
(Danyluk, 2017). Lefebvre explicitly connected the distinctive spatiality of late capitalism with processes of logistical calculation. "The production of space," he wrote, "is thought of in terms of logic or logistics. 'Space' seems to have a rational character, an implicit coherence which in turn implies practical cohesion" (Lefebvre, 1976: 27). Abstract space not only promotes ambient processes of production, distribution, and consumption; in its second function, it is also itself transformed into a commodity, and produced, distributed, and consumed as such (Stanek, 2011). Lefebvre was especially interested in the dynamics of urbanization, through which individual pieces of space are enrolled in the circulation of capital via processes of market exchange, profit-oriented development, and real estate speculation.

To serve its dual role as facilitator and object of accumulation, space must be subjected to systems of representation and procedures that allow it to be quantified-divided, measured, and compared with other pieces of space according to universal standards (Stanek, 2011). Just as Marx's concept of abstract labor designated those aspects of human productive activity that make the products of different acts of concrete labor commensurable and therefore capable of exchange on the market, Lefebvre's notion of abstract space underscores the exchangeability of individual pieces of space considered in isolation from their qualitative properties, natural features, and social meanings. Concrete space and abstract space are two aspects of the same phenomenon, either of which may be emphasized in a given social context. As Stanek (2011: 145) explains, "When Lefebvre claimed that abstract space is becoming 'true in practice,' he did not argue that concrete space vanishes but rather registered a preponderance of abstract space in economic, social, and everyday life practices."

As the exchange-value character of space acquires greater social meaning and material force, different component parts of space become increasingly interchangeable. In legal parlance, a commodity whose individual units are capable of mutual substitution is said to have the property of fungibility. Money, gold, and crude oil are fungible assets because any given quantity of each can be exchanged for any other equal quantity. Correspondingly, the hypothetical state in which any place is replaceable by any other might be called fungible space. Whereas Lefebvre's notion of abstract space refers to a whole suite of spatial practices "characterized by an isolation of functions, practices, and ideas" (Stanek, 2011: 142), fungibility diagnoses one specific implication of abstract space-the possibility of substituting one place for another. At the same time, it signals one of the social practices by which abstract space is brought into being: the enrollment of places into relations of substitution.

While a state of absolute spatial fungibility-implying the perfect interchangeability of all places-is impossible, it figures throughout the history of capitalism as an orientation or horizon. This tendency is especially pronounced in the world of commercial exchange and global commodity chains, as Lefebvre (1991: 341) himself noted: 
Chains of commodities (networks of exchange) are constituted and articulated on a world scale: transportation networks, buying- and selling-networks (the circulation of money, transfers of capital). Linking commodities together in virtually infinite numbers, the commodity world brings in its wake certain attitudes towards space, certain actions upon space, even a certain concept of space. Indeed, all the commodity chains, circulatory systems and networks, connected on high by Gold, the god of exchange, do have a distinct homogeneity. Exchangeability, as we have seen, implies interchangeability.

The fungible character of space in capitalist commodity circuits has been amplified by recent developments in logistics. The widespread adoption of the standardized shipping container, for example, has made it possible to move freight through multiple modes of transport without needing to unpack and repack it at each transfer point. Containerization and intermodalism have cheapened and accelerated the movement of goods, giving shippers and carriers unprecedented flexibility in their routing decisions. By reducing inland transport costs, they have also eroded seaports' monopolies over their traditional hinterlands, leaving ports more vulnerable to being expunged from the network (Hesse, 2013). In North America, the development of a robust intermodal system means that a significant share of imported freight is now considered "discretionary"-that is, not tied to a particular port of entry. Meanwhile, global shipping lines have reorganized their service networks according to a hub-and-spoke model linked together by transshipment, or ship-to-ship transfer. Because transshipment activity is not tied to a specific location, it can easily be relocated to any number of ports in the same region.

If these technological and organizational changes have accentuated the fungible quality of space in the logistics network, just as important have been the conceptual shifts that gave rise to the new business science of logistics management. As Cowen (2014) shows, the ascendancy of total-cost analysis and "systems thinking" in the 1960s opened up new ways of quantifying the spaces of the supply chain. The models used by logistics analysts treat location and distance as endogenous variables, data points to be measured and manipulated with an eye to maximizing profits across the entire cycle of production and distribution. Advances in computing power have enabled firms to quickly assess the financial implications of using an alternative route, port, carrier, or mode of transportation, encouraging them to treat space in terms of pure exchange value. Maersk Line's decision to divert container services from the Panama Canal to the Suez, resulting in the bizarre map shown above, is one manifestation of this spatial calculus.

Notably, the heightened substitutability of places within today's logistics chains means that not every actor in the network is on an equal footing. Those whose assets 
are relatively fixed in place, like ports, canals, railroads, and airports, must vie for business from relatively mobile actors, like shipping lines, airlines, and freight forwarders, as well as the manufacturers and retailers that employ them to move cargo. In practice, it is this second group, with their weak ties to place, who incite the drive toward fungibility in the logistics network. Footloose shippers and carriers, insofar as they can flexibly reroute shipments or reshape their service networks, can foment rivalries among place-bound actors in order to extract lower rates and other advantages. Global shipping lines, for instance, can and do use the threat of diverting cargo in order to play port authorities off against one another in negotiations (Fowler, 2006). This competitive dynamic promotes a race to the bottom among ports, driving down local revenues, environmental standards, and wages and working conditions on the docks.

The spatial practices of mobile actors within the logistics network-underpinned by processes of standardization, calculation, and optimization-are therefore a potent manifestation of capitalism's tendency to render space fungible. The ease with which footloose shippers and carriers can swap out places within corporate supply chains sets the stage for intense rivalries among geographically embedded actors to attract mobile cargo flows. Yet it is the efforts of this latter group that make such spatial substitutions possible in the first place. For not just any locality can insert itself into the logistics network: a place's competitiveness depends on specific local conditions whose fulfillment requires active and ongoing work. In this sense, the tendency toward spatial fungibility is accompanied by, and has as its very condition, an opposing movement toward geographical specificity. In the next two sections, I explore how this dialectic has played out in the dynamics surrounding the expansion of the Panama Canal, an infrastructure project that has had reverberations throughout the Americas.

\section{Shifting Trade Routes: The Panama Canal Expansion and the "Battle of the Ports"} On 26 June 2016, Panamanian authorities unveiled the first major upgrade to the country's famed canal since its inauguration in 1914. The Panama Canal expansion projectcompleted almost two years behind schedule and hundreds of millions of dollars over budget-involved outfitting the 77-kilometer waterway with a third set of locks and wider, deeper navigation channels. The canal's new shipping lane can accommodate vessels carrying more than 14,000 containers, almost three times the capacity of the largest ships that could previously use the route.

Within Panama, the expansion project enjoyed strong public support, having been approved by a wide majority of voters in a 2006 referendum. The Panama Canal Authority (ACP, by its Spanish initials), the government agency responsible for the waterway, had claimed that the upgrade was needed for three main reasons. First, the canal 
was quickly nearing its maximum capacity. Traffic on the world's oceans has quadrupled since 1992, putting increased pressure on global shipping lanes (Tournadre, 2014). As a consequence, vessels were regularly waiting up to 10 days to enter the Panama Canal (Knight, 2008). Second, the waterway was at risk of becoming obsolete owing to rapid growth in the size of cargo ships since the 1970 s. Over $55 \%$ of the world's seaborne containerized freight is now carried on "post-Panamax" vessels, so named because they are too big to fit through the canal's original locks (DSF, 2014). A third impetus came from global shifts in the geographies of commodity production. Since the 1980s, the offshoring of manufacturing, particularly to China, has resulted in a dramatic expansion of Asia-North America trade. As noted earlier, the Panama Canal had long been the preferred route for shippers moving Asian-produced goods to the large consumer populations of the North American East Coast, but by the turn of the century it was facing mounting competition from two alternative routes. One was the North American intermodal system, or "land bridge," by which containers are shipped across the Pacific, unloaded at deepwater ports along the US or Canadian West Coast, and then hauled eastward by train. The second threat to Panama was from the Suez Canal. Especially as manufacturing has migrated westward from China to low-wage countries on the Indian subcontinent, some shippers have begun routing Eastern Seaboard-bound cargoes through the Suez Canal and across the Atlantic.

For these reasons, the ACP warned, Panama's relevance as a global shipping lane was in jeopardy. The canal authority's 2006 master plan used the word competitividad (competitiveness) 44 times, driving home the imperative of ensuring the waterway's continued importance as a strategic route for maritime trade (ACP, 2006). In advance of the referendum, the ACP promoted the expansion project to Panamanian voters through a well-funded marketing campaign that made emotional appeals to patriotism, national prosperity, and what one spokesperson for the project described in an interview as Panama's "historical-geographical destiny as the crossroads of the world."

This was not the first time that changing transportation technologies and trading patterns had threatened Panama's importance as a commercial route. In the early Spanish colonial era, merchants had used Panama as a transit point for silver being transported from Peru to Madrid; beginning in the seventeenth century, however, competition from other interoceanic routes led to a drop in traffic across the isthmus, contributing to a sustained period of economic decline in Panama (Maurer and $\mathrm{Yu}$, 2011). This process repeated itself in 1869, when the opening of the US Transcontinental Railroad undercut the value of a railway that had been operating across Panama since 1855. Panama's relevance as a conduit of world trade is certain to come under threat again in the future as potential new routes, including a proposed canal through Nicaragua and the prospect of an ice-free Northwest Passage, loom on the horizon. 
Considered in light of this history, the project to expand the Panama Canal is only the latest scheme to enhance the country's attractiveness to international trade. Numerous Panamanian industry and government representatives, in interviews, invoked the country's turbulent history as a crossroads of global commerce and warned of the dangers that could ensue if capital once again decided to shift trade to other routes. Indeed, in business and policy circles, Panama's competitiveness as a maritime and logistics hub has become an existential concern. At the 2013 Panama Logistics Expo and the 2013 Panama Free Zones Expo Forum, an anxiety about the country's logistics performance permeated many of the speeches, with several presenters stressing Panama's vulnerable position vis-à-vis the capricious shipping lines. For the executive director of the Georgia Tech Panama Logistics Innovation and Research Center, growing the country's logistics sector was a matter not only of attracting ship traffic to the canal but of enticing carriers to conduct transshipment at Panama's ports:

Ports are pretty much, pretty much totally dependent on the shipping lines for transshipment. And it's really easy for the shipping lines to pick up their transshipment and move it somewhere else. We saw that happen in Singapore a few years ago.... We have some services now that have moved from going through the canal to going through the Suez Canal. So the shipping lines are a fairly fickle group.... They know where they think they can make the most money. So what has to happen is you have to make it attractive for them to make the most money by transshipping in Panama. And it's not just the ports, and it's not just the railroad, not just the trucking companies. Everybody who wants Panama to be a hub, who wants companies to come locate here to redistribute their products, need to do whatever they can to make the ports and the railroads a success with regard to transshipment.

Motivating such warnings is the intensification of competition for transshipment activity in Central America and the Caribbean, as numerous countries in the region have announced deepwater port projects in hopes of becoming regional hubs for the large ships transiting the widened Panama Canal.

But the impacts of the canal expansion reach far beyond Central America and the Caribbean. The ability to deploy larger, more cost-efficient ships through the waterway creates an incentive for some shippers and carriers to bypass ports on the West Coast of North America in favor of the all-water route via Panama to the Eastern Seaboard. The prospect of receiving these bigger ships and their bigger cargoes has sparked the entrepreneurial imaginations of port authorities along the North American East Coast, triggering what has been called a "battle of the ports" (CanagaRetna, 2010: 12; Spivak, 2011). Almost every major seaport from Halifax to Houston has been dredging its harbor, installing bigger cranes, expanding terminals, or improving road and rail connections in a bid to attract post-Panamax vessels. The Port of Miami recently declared itself 
"big ship ready" after deepening its navigation channel to 15 meters and building a new undersea tunnel for trucks. The Port Authority of New York and New Jersey is raising the deck of the Bayonne Bridge so that post-Panamax container ships can pass underneath it. Even smaller cities are entering the fray: Jacksonville, Florida, is debating a harbor-deepening project of its own, while investors in Sydney, Nova Scotia, have announced plans for a new deepwater port that would be able to handle the largest container ships in the world. Farther inland, state highway departments and railroads are making improvements to handle additional truck and train traffic. In the United States alone, over the five years leading up to the opening of the widened canal, port authorities and their private-sector partners were planning to spend an estimated $\$ 46$ billion on infrastructure (AAPA, 2012).

Exactly how much was at stake in this battle, however, was never clear. As work began on the Panama Canal expansion, industry analysts made wildly differing predictions about how the project would affect North American shipping patterns. At one extreme were those who claimed the canal's new locks would be a "game changer" (JLL, 2011: 1; O'Reilly, 2012: 60). According to this view, ports on the US West Coast would suffer a swift and dramatic decline in cargo volumes as shippers rerouted up to $25 \%$ of containerized imports through the widened canal to ports on the East and Gulf Coasts (DSCA, 2008; Dynamar, 2008). At the other extreme were those who maintained that the canal expansion would have no perceptible impact on traffic flows. These commentators noted that West Coast ports had already lost significant market share in recent years owing to congestion, labor unrest, and efforts by importers to diversify their supply chains (Prince, 2012; S. Smith, 2012; Weber Logistics, 2012).

Despite this uncertainty, the prevailing orientation toward the canal expansion among East Coast port authorities has been one of unbridled optimism. In an interview, a Panama-based reporter who covers the shipping industry said that the ports' expectations were overblown. "You have these big egos and big dreams. ... Everyone's just in this gold-rush mentality." In his view, the competitive structure of port governance and the lack of federal coordination were resulting in wasteful public spending and redundant infrastructure:

You really only need three ports along the East/Gulf Coast that need to be big enough for these ships. And you have, what, fifteen ports all trying to get ready.... It's just unreasonable. It's just blowing a lot of money, I think. They're going to get really, really burned. ... There's just this irrationality of thinking everyone wants to be that port. Whereas if you sort of get together at the government level and say, "OK, ... three ports are going to benefit. Let's pick them." And no one is doing that. They're saying everyone's got to get bigger. 
Perhaps the most dubious port scheme related to the Panama Canal is the Louisiana International Deep Water Gulf Transfer Terminal, a massive transshipment facility proposed for construction near the mouth of the Mississippi River (http://www.ligtt.com). The investment firm promoting the $\$ 1.3$ billion project, ABK Venture Group, is counting not only on significant diversion of cargo through the Panama Canal but also on luring traffic away from the well-established Port of New Orleans, just 160 kilometers upriver. $\mathrm{ABK}$ has proposed to fund the terminal using money from immigrant investors-foreigners eligible to gain permanent US residency by investing at least $\$ 500,000$ in an American company (Kulisch, 2014). One New York-based transportation consultant said that this "bizarre" financing scheme underscores the project's profoundly speculative character, betraying "a lack of confidence that anybody else is going to pay for it." He echoed the view that East Coast port interests have been too rosy in their expectations: "Everybody thinks that they're going to get a piece of the action. ... People are counting on big stuff to happen. But I think they're going to be largely disappointed." Time will tell how many of these ports have placed losing bets. In the meantime, excess terminal capacity along the East Coast will benefit shipping lines at the expense of port authorities (Tirschwell, 2012).

On the Pacific, meanwhile, the Panama Canal expansion is viewed as a threat. In an effort to maintain their dominance on transpacific container trades, West Coast port authorities and logistics interests have been pursuing competitive initiatives of their own. In Southern California, by far the leading gateway for Asian imports into North America, the Port of Long Beach is spending over a million dollars a day on a 10-year capital improvement program that includes the construction of a heavily automated container terminal and the replacement of a five-lane bridge with a wider, higher span. Union Pacific and BNSF, the two major railroads serving the western United States, have likewise stepped up their game in recent years, double-tracking their mainlines between Los Angeles and Chicago and building intermodal rail hubs in inland destinations like Memphis and Kansas City.

In Southern California, efforts to make the Ports of Los Angeles and Long Beach competitive with the enlarged Panama Canal can be understood as part of a larger regional strategy to promote goods-movement and logistics activities in the wake of decades of deindustrialization and the loss of white-collar employment (see De Lara, 2012). A key player in that agenda is the Southern California Association of Governments (SCAG), the metropolitan governance organization responsible for drawing up comprehensive freight-movement plans for the region. Particularly since the 2007-9 recession, the agency has worked to impress on politicians and the public the importance of trade and logistics to Southern California's economy. According to a transportation planner at SCAG, a significant diversion of cargo through the Panama Canal would represent a serious blow to the region's well-being: 
What does it mean for the local community? So if you see a lot of diversion, obviously that means jobs. It means tax revenues. It means just the general welfare of the city. And that awareness is really important, because a lot of times you don't realize how you're tied to the port. ... There's a lot of goods-movement-dependent industries that also generate a lot of jobs and revenue, not just logistics. So when we talk about losing that trade, it affects everybody throughout a number of industries.

From this perspective, Southern California has little choice but to adopt a competitive stance vis-à-vis the new Panama Canal. Maintaining and enlarging the stream of containers moving through the twin ports is seen as vital to the health and prosperity of the entire region.

In 2010, this entrepreneurial outlook crystallized in a campaign called Beat the Canal (http://www.beatthecanal.com), founded by two well-connected industry veterans in direct response to the impending completion of the widened Panama Canal and the attendant threat of cargo diversion. The initiative brought together the Ports of LA and Long Beach, BNSF Railway and Union Pacific Railroad, the International Longshore and Warehouse Union (ILWU), International Brotherhood of Electrical Workers Local 11, SCAG, and the Southern California Leadership Council. It also had the support of several prominent local politicians and the Los Angeles Times. The coalition campaigned aggressively for several years to expedite the construction of more than 60 freight-related infrastructure projects throughout the region, including port improvements, the replacement of a congested at-grade rail crossing with a new railway overpass, and two proposed intermodal rail terminals. As a policy director at SCAG explained, a key objective of the campaign was to raise awareness about the importance of logistics to Southern California's economy:

We needed a little bit of a rallying cry, to be honest with you, to move it through. So the Beat the Canal was perfect, because it was a very tangible thing. Whether or not it is devastating to our local economy or whether we lose a little bit, we don't really want to lose any. Right? So how do we think about what kind of investments we need to make, as a region and as a state, to ensure that we're going to lose as little market share as possible?

One of the founders of the Beat the Canal effort echoed this view, saying that the campaign was a "war cry" intended to bring together the disparate actors who share a stake in the regional goods-movement system. As the campaign's other founder explained, the Panama Canal project served as a powerful motivator:

I put a lot of pressure on the port, and Port of LA kind of responded with a competitive strategy, which they had never had. . . Nobody was thinking about it. They thought, "What the hell are you talking about?" And I said, "You wait. We're going 
to start Beat the Canal.” They thought, "Which canal?” I said, "Panama." . . Y You have to understand, in Southern California, if you don't pick a good enemy, we will pick each other as the enemy. So we've got to have an enemy everybody'll agree to.

Speaking in 2014, the same industry veteran pronounced the Beat the Canal campaign a success. Thanks in part to construction delays in Panama, almost all the infrastructure projects in the regional portfolio had been completed before the opening of the canal's new locks. More importantly for him, the initiative had instilled a new entrepreneurial mindset in Southern California's logistics stakeholders:

A lot of people have gotten on board. Now they mention competition, the first thing out of their mouth is, "Yes, the Panama Canal." ... So we were very effective. It was an effective theme.

The argument elaborated so far has suggested a fairly straightforward conception of fungible space. The ACP's initiative to expand the Panama Canal in order to remain competitive with the Suez Canal and the North American land bridge points to the substitutability of paths (canals, oceans, railways) within the logistics network, while the project's implications for North American cargo patterns highlight the substitutability of nodes (transshipment points, port gateways). The optimism and anxiety on the part of place-based actors in the container-shipping network are a testament to the flexible shape of today's supply chains and the ease with which shippers and carriers can divert commodity flows to alternative routes. Yet the competitive activities of those spatially fixed actors - many of whom are going to considerable lengths to accommodate larger ships and more cargo-hint at the work entailed in making such geographic substitutions possible. In the next section I explore some of the conditions of spatial fungibility in more detail.

\section{The Conditions of Fungibility}

Cargo owners and transportation providers take into account a range of considerations-locational, technical, legal, cultural, economic, political—when making decisions about how and where to route goods flows. For place-bound actors seeking to attract logistics activities to their jurisdictions, satisfying these requirements entails considerable and ongoing effort. The discussion here touches on six conditions of fungibility in the container-shipping network: infrastructure, institutional and regulatory frameworks, network integration, place marketing, labor relations, and political climate.

Among the fundamental preconditions of a place's insertion into the logistics network are the industry's requirements for large-scale infrastructure, often in the form of speculative megaprojects involving considerable public investment. As Jaffee (2015: 
790) notes, the provision of the appropriate infrastructure is a "necessary, but ultimately insufficient, condition for achieving the economic development objectives," since there is no guarantee that ships will actually call at a port facility once it is built. In container shipping, the necessary infrastructure comprises waterside elements (navigation channels, breakwaters, bridge clearances) and landside elements (berths, container yards, cranes, road and rail connections), as well as the various components of the wider regional logistics system (truck routes, intermodal rail terminals, warehouse space). Developing these facilities often entails dramatic modifications to the natural environment and costly environmental impact studies, as in the case of land-reclamation or harbordredging works. These circumstances favor port cities that already have the necessary infrastructural endowments. A communications officer at the Port of Long Beach was one of several informants who said that Southern California's well-developed logistics infrastructure gives it a competitive edge over the East Coast:

Just staying pace with economic growth is an issue at ports, because the investments are so big, and they take so long. ... It's one of our advantages that we have this network here. ... When you ask about the Panama Canal and, "Oh, yeah. OK, let's just deepen the harbor and bring in a new crane," no, that's not enough.

The challenges do not end with the initial provision of the fixed capital. Ports face continual pressure to expand and modernize their facilities if they are to remain competitive. This is particularly salient given the growing size of container ships. The consolidation of the industry around a handful of global carriers, the proliferation of vesselsharing alliances, and the growth of transshipment have all concentrated cargo onto increasingly large vessels. The Long Beach official elaborated on the challenges this trend poses for port regions:

The thing that's clearly come out of the recession is that everybody needs to be more productive, more cost effective in everything they do. And among the ways that the industry's moving toward that is employing bigger and bigger ships, to reduce the unit costs. But that means that everybody in the supply chain has to deal with having that massive volume of cargo coming to your port or your rail yard or your warehouse. ... With each ship_-and we're fortunate we have deep waters-not only do the waters have to be deeper, but the channels have to be wider. And then, like I say, cranes have to be taller and reach out further. There's so many improvements, and every improvement is a million here and a million there, and pretty soon you're into a billion there and a billion there.

Port-expansion schemes are rendered doubly speculative by the fact that infrastructure development is often subject to forces beyond local control. In the United States, harbordredging projects must be approved by the US Army Corps of Engineers, and federal 
funding appropriations then secured from Congress (Jaffee, 2015). With dozens of ports vying for limited resources, support is far from guaranteed.

A second factor affecting a place's attractiveness to mobile logistics actors is the local institutional and regulatory context. Such preoccupations have been central to logisticsoriented development efforts in Panama. In recent years, officials and business leaders have formed a dizzying array of public, private, and public-private bodies to enhance the country's position as a distribution and transshipment hub, including a Competitiveness and Logistics Secretariat, a Logistics Cabinet, a National Logistics Council, and a Logistics Business Council (SCL, 2017). The national government and private sector are collaborating with the World Bank, the Inter-American Development Bank, and the Andean Development Corporation-Development Bank of Latin America. These supranational bodies have provided funding, facilitation, and technical support to assist in restructuring the country's institutional and legal frameworks, developing infrastructure, and formulating a national logistics plan. The Panamanian government has also partnered with the Georgia Institute of Technology to create the Georgia Tech Panama Logistics Innovation and Research Center, which aims to improve the country's logistics performance through research and education (http://www.gatech.pa).

Logistics-based growth strategies face a third challenge in that the goods-movement network is not a seamlessly integrated system or a cohesive operational unit, as it is often depicted by the industry, but a fragmentary, unstable ensemble of physical and social infrastructures that are conceived, constructed, and managed by formally independent actors. No central entity coordinates investment or operational decisions with an eye to the functioning of the system as a whole. Yet, as the Panama Canal expansion illustrates, different sites in the network are bound together in complex relations of contingency and interdependence. The returns on the investments made by North American port authorities hinged on the timely completion of the canal project, as well as on the activities of rival ports. Likewise, the Panama Canal Authority's ability to attract postPanamax ships to its new locks in June 2016 depended in part on whether terminals on the North American East Coast were ready to accept those larger vessels. The fragmented but interdependent character of transportation infrastructure thus creates considerable uncertainty for logistics-oriented entrepreneurial schemes.

Similar dynamics are at play at a smaller scale, where integration of the various elements of the regional freight network is an important factor in a place's logistics competitiveness. Speaking at a forum, Georgia Tech Panama's executive director explained that the greatest obstacle to increasing transshipment activity in Panama was the lack of coordination among the country's numerous port, rail, and truck operators:

Integration of all these pieces is essential. They all belong to different entities, they're all private, and so it's not at all easy to get integration among these private entities. 
In fact, it's pretty surprising that they're all working together to try to make this happen. I guess it's not so surprising if you think about the fact that it's in everybody's best interest.

As he stressed, Panama's highly favorable geographic location at the narrowest point between the two oceans was not enough to make it a successful cargo hub: "This takes a tremendous amount of work." The fungibility of space, such statements make clear, has to be actively produced.

That work may also involve promoting a place to logistics operators. In 2009, six US port authorities from Seattle to Long Beach partnered with BNSF and Union Pacific on a joint marketing arrangement called the US West Coast Collaboration. In the wake of the economic crisis and in anticipation of the expansion of the Panama Canal, the coalition worked to promote the advantages of the West Coast's ports and intermodal system to shippers and carriers. Those benefits, repeatedly enumerated by interviewees, include naturally deep harbors, frequent vessel services, extensive rail and road infrastructure, excellent maritime and inland connectivity, and abundant warehouse space. But the US West Coast Collaboration should also be situated against the backdrop of years of negative press, and diverted cargo, after a labor disruption in 2002 and severe gridlock during the 2004 holiday season cost retailers millions of dollars. In the first event, a dispute between the Pacific Maritime Association and some 7,000 members of the ILWU culminated in a lockout that shut down US West Coast ports for 10 days. The incident contributed to a widespread perception of labor militancy along the Western Seaboard. In the wake of these events, the industry collaboration sought to assure shippers of the reliability of the West Coast ports, emphasizing their "proven track record" and "ample labor force" on its website.

Indeed, labor relations are crucial to competitiveness in logistics, which puts a high value on reliability (Jaffee, 2010). After the US West Coast port lockout, retailers, shipping lines, and port authorities came together to identify and develop alternate points of entry on the East and Gulf Coasts; the widening of the Panama Canal was viewed as a "critical component" of this strategy (CanagaRetna, 2010: 9). The Panama-based reporter described the lasting reputational damage done by the 2002 labor dispute: "That sticks with shippers. They remember that. And they don't like the uncertainty. ... I think these guys will be happy not to be on the West Coast." As the canal expansion project neared completion, shipping lines used the threat of diverting cargo through Panama to exercise discipline over West Coast longshore workers (Zerolnick, 2012). By some reports, this strategy was effective, pushing dockworkers in Los Angeles and Long Beach to accept compromises in contract negotiations. As one industry consultant said, 
the ILWU "has tempered its wage demands as these large ships threaten to disintermediate that port, as a larger Panama Canal threatens to disintermediate that port, and as ports in Mexico threaten to disintermediate that port."

Finally, a crucial condition of spatial fungibility in the freight network is local political support for logistics-based development (see Jaffee, 2015). The case of the Southern California International Gateway (SCIG), an intermodal rail facility proposed by BNSF Railway and the Port of Los Angeles, illustrates how community opposition can play a decisive role in shaping the larger logistics network. In 2005, BNSF announced a plan to replace its existing transfer yard, located some 30 kilometers north of the ports in the city of Commerce, with a new, larger terminal near the docks. The SCIG project was touted as a state-of-the-art, environmentally friendly facility that would create jobs, reduce congestion, and improve air quality, in part by eliminating more than 1.5 million truck trips from the busy I-710 freeway each year (Port of Los Angeles, 2013). In interviews, Southern California public officials and business interests consistently described the project as vital to maintaining the region's economic competitiveness. Others disagreed. A total of seven different lawsuits were brought against BNSF and the port over the project. The breadth of opposition was unusual, with the litigants including the City of Long Beach, community and environmental groups, the Long Beach Unified School District, the South Coast Air Quality Management District, and transportation companies with business at the ports. The plaintiffs argued that SCIG would increase emissions, noise, and truck traffic, harming the health of residents and schoolchildren in west Long Beach-a low-income, predominantly Latino community that is already home to a major rail yard. In 2016, a California superior court ruled in their favor, halting construction on the $\$ 500$ million SCIG project. In his decision, the judge said that BNSF and the Port of LA had failed to adequately assess the project's environmental impacts. While the proponents have appealed the decision, grassroots environmental justice movements have dealt Southern California logistics interests a major blow in their campaign to beat the Panama Canal and their larger strategy to increase the volume of cargo moving through the region.

This analysis of the network of change and contestation surrounding the expansion of the Panama Canal undermines any simplistic notion of fungibility as a property that inheres in space itself. On the contrary, it illustrates the work-material, discursive, and affective-that goes into attracting fickle commodity flows and the economic activities associated with them. The substitutability of nodes and paths within the logistics network is not a preexisting property of places themselves but a condition that is actively produced through concerted effort. To conclude, I consider what is at stake in these speculative ventures, highlighting the costs and risks of logistics-based growth schemes for workers and communities caught in a volatile web of competition for commodity flows. 


\section{Conclusion}

Throughout the Americas, the expansion of the Panama Canal has sparked a flurry of entrepreneurial activity on the part of place-based actors seeking to capture footloose freight flows and the economic benefits purportedly attached to them. The anxiety over logistics competitiveness and cargo diversion, the feverish pace of infrastructure expansion, and the formation of novel alliances attest to the rising prominence of goods movement in local, regional, and national growth strategies. At the same time, the circulation of commodities through global logistics systems binds places together in complex relations of interdependence, contingency, and risk. What are the prospects for localities seeking to insert themselves into these networks?

I have argued that the heightened substitutability of places within the logistics network has rendered supply chains highly unpredictable and intensified rivalries among geographically situated actors for footloose commodity flows. Together, the relative powerlessness of those actors vis-à-vis mobile capital, the industry's requirements for large-scale infrastructure, and places' vulnerability to forces beyond local control combine to make logistics-based development a highly risky growth strategy. It is far from clear that these risks are outweighed by the rewards. Compared with schemes to attract conventional production or consumption activities, logistics-oriented growth strategies create little in the way of local economic benefits. Because most of the goods moved through a region are destined for somewhere else, they generate no local sales-tax revenue. The benefit most frequently cited by boosters-jobs-is often vastly overstated (Jaffee, 2015). Moreover, because distribution networks can be easily reorganized, what payoffs do flow from such strategies tend to be ephemeral.

The dubious and fleeting benefits of schemes to attract commodity flows must be weighed against those initiatives' clear negative social, economic, and ecological impacts. As place-based elites and officials go to growing lengths to capture cargo, the costs and risks are disproportionately borne by the most vulnerable actors in the network. Studies suggest that the true casualties in the "battle of the ports" are not ports as such but the communities and workers who live and labor in the pathways of global trade (R. Smith et al., 2010; HIP, 2011; Hricko, 2012). These groups, who are disproportionately poor and racialized, subsidize cheap shipping through stolen wages, precarious work, environmental degradation, cumulative health impacts, and the dispossession of homes and resources.

Paradoxically, then, the fantasy of smooth, frictionless circulation rests on moments of turbulence and upheaval. Yet the harms of the global logistics system have not gone unchallenged. The violence wrought by this contemporary form of capitalist abstraction has met with potent resistance at key crossroads of trade-places like Colón, Panama; Busan, South Korea; and Oakland, California. Such struggles serve as a reminder that 
while the structural logic of interspatial competition exerts powerful coercive pressures, it does not unfold automatically or independently of people's concrete actions.

\section{Acknowledgments}

For thoughtful comments on earlier versions of this paper, sincere thanks go to Wes Attewell, Neil Brenner, Michelle Buckley, Dan Cohen, Deborah Cowen, Emily Gilbert, Kanishka Goonewardena, Scott Prudham, Max Ritts, and Laura Vaz-Jones.

\section{Author Biography}

Martin Danyluk is a Social Sciences and Humanities Research Council of Canada Postdoctoral Fellow in the Department of Geography at the University of British Columbia. He has a $\mathrm{PhD}$ in geography and an MSc in urban planning from the University of Toronto.

\section{References}

AAPA (American Association of Port Authorities) (2012) U.S. port infrastructure investment survey, 2012 - 2016. (Alexandria, VA). URL http://aapa.files.cmsplus.com/2012\%20AAPA \%20Port \%20Infrastructure $\% 20$ Spending $\% 20$ Survey $\% 20$ Summ ary.pdf (accessed 23 July 2017).

ACP (Panama Canal Authority) (2006) Plan maestro del canal de Panamá (Panama Canal master plan). Panama City.

Allen, W.B. (1997) The logistics revolution and transportation. Annals of the American Academy of Political and Social Science 553.1, 106-16.

Bonacich, E., and J.B. Wilson (2008) Getting the goods: Ports, labor, and the logistics revolution. Cornell University Press, Ithaca, NY.

Brenner, N. (2003) "Glocalization" as a state spatial strategy: Entrepreneurialism and the new politics of scale. In J. Peck and H.W.-c. Yeung (eds.), Remaking the global economy: Economic-geographical perspectives, Sage, London.

CanagaRetna, S.M. (2010) The Panama Canal expansion and SLC state ports. Southern Legislative Conference (Atlanta). URL http://www.slcatlanta.org/Publications/EconDev/ports_web.pdf (accessed 23 July 2017).

Cowen, D. (2014) The deadly life of logistics: Mapping violence in global trade. University of Minnesota Press, Minneapolis.

DSF (Danish Ship Finance) (2014) Shipping market review, May 2014. URL http://www.shipfinance.dk/media/1054/shipping-market-review-may-2014.pdf (accessed 23 July 2017). 
Danyluk, M. (2017) Capital's logistical fix: Accumulation, globalization, and the survival of capitalism. Environment and Planning D: Society and Space, early online edition, 1-18.

De Lara, J.D. (2012) Goods movement and metropolitan inequality: Global restructuring, commodity flows, and metropolitan development. In P.V. Hall and M. Hesse (eds.), Cities, regions and flows, Routledge, London.

DSCA (Drewry Supply Chain Advisors) (2008) US transpacific intermodal today and tomorrow. Drewry Shipping Consultants, London.

Dynamar (2008) Panama Canal container trades: Present and future. Alkmaar, Netherlands.

Fowler, C.S. (2006) Reexploring transport geography and networks: A case study of container shipments to the West Coast of the United States. Environment and Planning A 38.8, 1429-48.

Hall, T., and P. Hubbard (eds.) (1998) The entrepreneurial city: Geographies of politics, regime, and representation. Wiley, New York.

Hart, G. (2006) Denaturalizing dispossession: Critical ethnography in the age of resurgent imperialism. Antipode 38.5, 977-1004.

Hart, G. (2016) Relational comparison revisited: Marxist postcolonial geographies in practice. Progress in Human Geography, early online edition, 1-24.

Harvey, D. (1989) From managerialism to entrepreneurialism: The transformation in urban governance in late capitalism. Geografiska Annaler: Series B, Human Geography 71 B.1, 3-17.

Hesse, M. (2013) Cities and flows: Re-asserting a relationship as fundamental as it is delicate. Journal of Transport Geography 29, 33-42.

HIP (Human Impact Partners) (2011) I-710 Corridor Project health impact assessment. (Oakland, CA). URL http://www.humanimpact.org/downloads/a-health-impactassessment-of-the-i-710-corridor-project-in-los-angeles-2/ (accessed 23 July 2017).

Hricko, A. (2012) Progress and pollution: Port cities prepare for the Panama Canal expansion. Environmental Health Perspectives 120.12, A470-3.

Jaffee, D. (2010) Labor and the geographic reorganization of container shipping in the U.S. Growth and Change 41.4, 520-39.

Jaffee, D. (2015) “A deeper channel floats all boats": The port economy as urban growth engine. Environment and Planning A 47.4, 783-800.

Jonas, A.E.G., and D. Wilson (eds.) (1999) The urban growth machine: Critical perspectives, two decades later. State University of New York Press, Albany.

JLL (Jones Lang LaSalle) (2011) The Panama Canal's impact on U.S. industrial real estate. (Chicago). URL http://www.us.jll.com/united-states/en-us/Research/Panama-Canalexpansion.pdf (accessed 23 July 2017).

Knight, K. (2008) The implications of Panama Canal expansion to U.S. ports and coastal navigation economic analysis. Institute for Water Resources, US Army Corps of Engineers (Alexandria, VA). URL

http://www.iwr.usace.army.mil/Portals/70/docs/iwrreports/WhitePaperPanamaCanal.pdf (accessed 23 July 2017).

Kulisch, E. (2014) Is LIGTT legit? American Shipper, February, 46-56. 
Lefebvre, H. (1976) The survival of capitalism: Reproduction of the relations of production. F. Bryant (trans.). St. Martin's, New York.

Lefebvre, H. (1991) The production of space. D. Nicholson-Smith (trans.). Blackwell, Malden, MA.

Logan, J.R., and H.L. Molotch (1987) Urban fortunes: The political economy of place. University of California Press, Berkeley.

Maurer, N., and C. Yu (2011) The big ditch: How America took, built, ran, and ultimately gave away the Panama Canal. Princeton University Press, Princeton, NJ.

Molotch, H. (1976) The city as a growth machine: Toward a political economy of place. American Journal of Sociology 82.2, 309-32.

Negrey, C., J.L. Osgood, and F. Goetzke (2011) One package at a time: The distributive world city. International Journal of Urban and Regional Research 35.4, 812-31.

O’Reilly, J. (2012) Panama Canal: More questions than answers. Inbound Logistics, December.

Park, K. (2013) Maersk Line to dump Panama Canal for Suez as ships get bigger. Bloomberg, 11 March. URL http://www.bloomberg.com/news/articles/2013-03-11/maersk-line-todump-panama-canal-for-suez-as-ships-get-bigger (accessed 23 July 2017).

Peck, J., and A. Tickell (2002) Neoliberalizing space. Antipode 34.3, 380-404.

Port of Los Angeles (2013) Southern California International Gateway project: Final environmental impact report. URL http://www.portoflosangeles.org/EIR/SCIG/FEIR/01_Introduction_SCIG_FEIR.pdf.

Prince, T. (2012) Panama Canal expansion: Game changer, or more of the same? CSCMP's Supply Chain Quarterly, Quarter 1. URL

http://www.supplychainquarterly.com/topics/Logistics/201201panama/ (accessed 23 July 2017).

SCL (Competitiveness and Logistics Secretariat) (2017) Plan estratégico logístico 2015-2019 (Logistics strategic plan, 2015-2019). Government of Panama, 17 February. URL http://www.competitividad.gob.pa/Noticias/Plan-Estrategico-Logistico-2015-2019(accessed 23 July 2017).

Smith, R., D. Bensman, and P.A. Marvy (2010) The big rig: Poverty, pollution, and the misclassification of truck drivers at America's ports. National Employment Law Project and Change to Win.

Smith, S. (2012) Panama Canal expansion impacts: Myths and misconceptions. EFR, June. URL http://efr.wsp-pb.com/publications/default.aspx?id=35 (accessed 23 July 2017).

Sowers, E., P.S. Ciccantell, and D.A. Smith (2014) Comparing critical capitalist commodity chains in the early twenty-first century: Opportunities for and constraints on labor and political movements. Journal of World-Systems Research 20.1, 112-39.

Spivak, J. (2011) The battle of the ports. Planning, May/June.

Stanek, Ł. (2011) Henri Lefebvre on space: Architecture, urban research, and the production of theory. University of Minnesota Press, Minneapolis.

Tirschwell, P. (2012) Excess capacity trumps East Coast port battles for investment. Journal of Commerce, 13 April. URL http://www.joc.com/excess-capacity-trumps-east-coast-portbattles-investment_20120413.html (accessed 23 July 2017). 
Tournadre, J. (2014) Anthropogenic pressure on the open ocean: The growth of ship traffic revealed by altimeter data analysis. Geophysical Research Letters 41.22, 7924-32.

Wachsmuth, D. (2017) Infrastructure alliances: Supply-chain expansion and multi-city growth coalitions. Economic Geography 93.1, 44-65.

Ward, K. (2010) Towards a relational comparative approach to the study of cities. Progress in Human Geography 34.4, 471-87.

Weber Logistics (2012) Panama Canal expansion: Impact on the volume of imports to Southern California. URL http://cdn2.hubspot.net/hub/170754/file-18465977-

pdf/docs/panama-canal-expansion-whitepaper-weber-logistics.pdf (accessed 23 July 2017).

Zerolnick, J. (2012) Shippers' Panama Canal threat: Real or bluff? Capital and Main, 12 March. URL http://capitalandmain.com/shippers-panama-canal-threat-real-or-bluff (accessed 23 July 2017). 